\title{
BREAST FEEDING PRACTICES IN CHILDREN WITH SEPSIS ADMITTED IN INTENSIVE CARE.
}

1. MBBS, FCPS Pediatric Medicine Senior Registrar Pediatric Medicine Quaid-I-Azam Medical College/ Civil Hospital Bahawalpur.

2. MBBS, FCPS Pediatric Medicine, FCPS Neonatology Assistant Professor Neonatology Quaid-I-Azam Medical College/ Civil Hospital Bahawalpur.

3. MBBS, FCPS (Gynae) Senior Registrar Gynae \& Obs. Quaid-I-Azam Medical College/ Civil Hospital Bahawalpur.

4. MBBS, FCPS Pediatric Medicine Associate Professor Pediatric Medicine

Quaid-I-Azam Medical College/

Civil Hospital Bahawalpur.

Correspondence Address:

Dr. Ali Hammad

Senior Registrar Pediatric Medicine

Quaid-I-Azam Medical College/

Civil Hospital Bahawalpur.

ali.hammad20@gmail.com

Article received on:

23/05/2019

Accepted for publication:

09/08/2019

\section{Ali Hammad1, Hafiz Muhammad Anwar², Sadia Latif ${ }^{3}$, Malik Muhammad Naeem ${ }^{4}$}

ABSTRACT... Objectives: The objective was to study breast feeding practices in children with sepsis admitted in intensive care unit of Children Hospital, Lahore. Study Design: Descriptive cross-sectional study. Setting: Medical Intensive Care Unit of The Children Hospital and Institute of Child Health Lahore. Period: From June 2018 to December 2018. Material \& Methods: Considering $95 \%$ confidence level, $7.5 \%$ margin of error and the expected percentage of bottle feeding children i.e. $27 \%$ (least among both) feeding types in children with sepsis admitted in ICU, a sample size of 140 children was taken. All the patients from 6 month to 2 years of age and either gender admitted in medical ICU with sepsis were included in the study through nonprobability consecutive sampling. After taking an informed written consent from caregiver, a preformed and pre-tested questionnaire was used for data collection. Diagnosis of sepsis as based upon the criteria for SIRS. Exclusively breastfed children for first 6 months of life were classified as 'breastfed'. Data was analyzed using SPSS version 22 and Chi-square test. P value < 0.05 was taken as significant. Results: Total 140 children were included in the study with the mean age of $14.64 \pm 5.26$ months. In this study, 47 (33.57\%) children were found breast fed while 93 (66.43\%) children were not breast fed as per history. Conclusion: The study concluded that breast feeding practice is uncommon in children admitted in intensive care unit with sepsis and breastfeeding was found to be significantly associated with maternal education and gender of the child.

Key words: Breastfeeding, Intensive Care, Infants, Systemic Inflammatory Response Syndrome (SIRS), Sepsis.

Article Citation: Hammad A, Anwar HM, Latif S, Naeem MM. Breast feeding practices in children with sepsis admitted in intensive care. Professional Med J 2020; 27(5):935-938. DOI: 10.29309/TPMJ/2020.27.05.3748

\section{INTRODUCTION}

One of the best source of nutrients for infants is breast milk which is helpful for their growth. Breast feeding should be started as early as possible by feeding the colostrum as recommended by World Health Organization. ${ }^{1}$

WHO advocates exclusive breast feeding for initial 6 months of infant's life and after that infants should get nutritious and safe complementary feed up to 2 years while taking breast feed. Childhood morbidity and mortality increases if children are not breastfed especially exclusively breastfed during first 6 months of life. About half of all childhood deaths worldwide are associated with poor nutrition. Malnutrition causes poor immunity and therefore these children have more chances to die of diarrhea and respiratory tract infections which are very common in our society. ${ }^{2,3,4}$ In most cases of preventable deaths worldwide, malnutrition is the main cause and it can be eliminated through adequate breast feeding. Despite of the well-recognized role of exclusive breast feeding in health, it is not widely practiced in developing countries like Pakistan. In Pakistan, exclusive breast feeding rate is $37 \%$ during the initial 6 months of life which is also alarming. ${ }^{5}$

In a recent study, sepsis was found in $22 \%$ children with breast feeding and $16.7 \%$ children with bottle feed. ${ }^{6}$ While Shiva $F$ et al reported the frequency of sepsis as $27.2 \%$ bottle fed and $22.2 \%$ breastfed children. ${ }^{7}$

Sepsis in pediatric age group is one of the growing 
issues in developing countries. According to WHO and UNICEF, in 2008, about 8 million children who died under 5 years age, about $70 \%$ of deaths were due to common infectious diseases like pneumonia, malaria, measles, diarrhea, influenza. ${ }^{8}$ Protective effect of breast feeding against these infections is already proven and well known. But limited data is available on preventive effect of breast feeding against sepsis.

Inorderto determinethefrequency ofbreastfeeding in children with sepsis this study was designed. Considering the paucity of data available on this important condition which is associated with high morbidity and mortality in children, it is necessary to conduct a study with appropriate sample size to clarify the role of breastfeeding in children with sepsis. Latest data may highlight the link between breastfeeding practices and childhood sepsis. The result will help future studies to understand the role of breastfeeding practices in sepsis.

The objective was to study breast feeding practices in children with sepsis admitted in the Intensive care unit of The Children Hospital, Lahore.

\section{MATERIAL \& METHODS}

This was a descriptive cross-sectional study and was conducted in Intensive Care Unit of The Children Hospital and Institute of Child Health Lahore from June 2018 to December 2018 after approval from hospital ethical committee. Considering 95\% confidence level, $7.5 \%$ margin of error and the expected percentage of bottle feeding children i.e. $27 \%^{5}$ (least among both) feeding types in children with sepsis admitted in ICU, a sample size of 140 children was taken. All the patients from 6 month to 2 years of age and either gender admitted in medical ICU with sepsis were included in the study through non-probability consecutive sampling. Children having any anatomical defect making breast feeding impossible or if mother was not available for breastfeeding after child birth, were excluded. After taking an informed written consent from caregiver, a preformed and pretested questionnaire was used for data collection, mentioning that this information will only be used for research purposes and their secrets will be kept confidential. Sepsis was diagnosed after applying criteria for SIRS. The criteria for SIRS include tachycardia ( $>2$ SD of mean for age), tachypnea ( $>2$ SD of mean for age), temperature (less than $98.6 \circ \mathrm{F}$ or above $100.4 \circ \mathrm{F}$ ), and leukocyte count $\left(<4000\right.$ cells $/ \mathrm{mm}^{3}$ or $>12000$ cells $\left./ \mathrm{mm}^{3}\right)$. The presence of any two of the above was considered as sepsis. Children who were exclusively breastfeed for first 6 months of life were labeled 'breastfed'. All the collected data was analyzed on SPSS version 22. Categorical variables like gender and feeding types were presented in frequencies and percentages. Mean + S.D were calculated for continuous variable like age. To deal with the effect modifiers data stratification was done for age, gender, socioeconomic status and mother's literacy level and then chi-square test was applied. Significant $P$ value was taken $<0.05$.

\section{RESULTS}

Out of total 140 patients included in the study the mean age as $14.64 \pm 5.26$ months with age range of 6 months to 24 months. In this study, 47 (33.57\%) children were not breastfeed while 93 $(66.43 \%)$ children had breast feeding. Stratification of breastfeeding frequency with literacy level of mother showed that frequency of breastfeeding is high among educated women as compared to their counterpart $(p=0.000)$. The gender of child also significantly affected breastfeeding $(p=0.005)$. The majority of the children $(66.0 \%)$ with no history of breastfeeding were female. The weight of the child and monthly family income has no association with breastfeeding. Table-I

\begin{tabular}{|l|c|c|}
\hline Breastfeeding & Frequency & Percentage \\
\hline Yes & 93 & $66.43 \%$ \\
\hline No & 47 & $33.57 \%$ \\
\hline Total & 140 & $100 \%$ \\
\hline \multicolumn{2}{|c|}{ Table-I. Frequency of breastfeeding in patients. } \\
\hline \multicolumn{2}{|c|}{} \\
\hline
\end{tabular}

Stratification of breastfeeding frequency with literacy level of mother showed that breastfeeding was more common among educated women than their counterpart. 


\begin{tabular}{|c|c|c|c|c|c|}
\hline \multirow[t]{2}{*}{ Variable } & \multicolumn{4}{|c|}{$\begin{array}{c}\text { Breastfeeding } \\
\text { Yes No }\end{array}$} & \multirow[t]{2}{*}{ P-Value } \\
\hline & Frequency & Percentage & Frequency & Percentage & \\
\hline $\begin{array}{l}\text { Literacy level of Mother } \\
\text { Unable to read and write } \\
\text { Up to primary } \\
\text { Up to matriculation } \\
\text { Graduation and above }\end{array}$ & $\begin{array}{l}21 \\
13 \\
34 \\
25\end{array}$ & $\begin{array}{l}22.6 \% \\
14.0 \% \\
36.6 \% \\
26.8 \%\end{array}$ & $\begin{array}{l}24 \\
13 \\
07 \\
03\end{array}$ & $\begin{array}{l}51.1 \% \\
27.6 \% \\
14.9 \% \\
06.4 \%\end{array}$ & 0.000 \\
\hline $\begin{array}{l}\text { Mother's working status } \\
\text { Housewife } \\
\text { Working Lady }\end{array}$ & $\begin{array}{l}65 \\
28\end{array}$ & $\begin{array}{l}69.9 \% \\
30.1 \%\end{array}$ & $\begin{array}{l}39 \\
08\end{array}$ & $\begin{array}{l}82.9 \% \\
17.1 \%\end{array}$ & 0.09 \\
\hline $\begin{array}{l}\text { Gender of patient } \\
\text { Male } \\
\text { Female }\end{array}$ & $\begin{array}{l}55 \\
38\end{array}$ & $\begin{array}{l}59.1 \% \\
40.9 \%\end{array}$ & $\begin{array}{l}16 \\
31\end{array}$ & $\begin{array}{l}34.0 \% \\
66.0 \%\end{array}$ & 0.005 \\
\hline $\begin{array}{l}\text { Weight of patient } \\
>6 \mathrm{~kg} \\
\leq 6 \mathrm{~kg}\end{array}$ & $\begin{array}{l}42 \\
51\end{array}$ & $\begin{array}{l}45.2 \% \\
54.8 \%\end{array}$ & $\begin{array}{l}18 \\
29\end{array}$ & $\begin{array}{l}38.3 \% \\
61.7 \%\end{array}$ & 0.43 \\
\hline $\begin{array}{l}\text { Monthly family income } \\
<50,000 \\
\geq 50,000\end{array}$ & $\begin{array}{l}66 \\
27\end{array}$ & $\begin{array}{l}70.9 \% \\
29.1 \%\end{array}$ & $\begin{array}{l}35 \\
12\end{array}$ & $\begin{array}{l}74.5 \% \\
25.5 \%\end{array}$ & 0.66 \\
\hline
\end{tabular}

Table-II. Socio-demographic characteristics and breastfeeding.

Among the women who breastfed their children $36.6 \%$ had education up to matriculation and $26.8 \%$ were graduate or higher level of education. The education of women was found to be significantly associated with breastfeeding $(p=0.000)$. Among breast feeding women, $69.9 \%$ were housewives and $30.1 \%$ were working ladies. The gender of child was also found to be significantly affecting feeding practice $(p=0.005)$. The majority of the children $(66.0 \%)$ with no history of breastfeeding were female. The weight of the child and monthly family income has no association with breastfeeding as shown in TableII.

\section{DISCUSSION}

The immune system of children of 1-2 years age is in developing stage. Development of immune system depends much upon exposure to gut micro flora. The secretory IgA immune globulins present in mother's milk play a vital role. It also limits the bacterial translocation through neonate's gut mucosa. In this way breast milk protects the neonate and infant from common infections and sepsis. This defense mechanism of breast milk limits infections at gut mucosal level. Therefore many western countries have adopted the WHO policy of exclusive breast feeding for first 6 months of life while many countries recommend introduction of complementary feeding at 4 to 6 months of age.

A study done in Uganda reported that laboratory confirmed sepsis was found in $22 \%$ breastfed children and $16.7 \%$ bottle fed children. ${ }^{9}$ In our study the frequency of breastfeeding is high among educated mothers as compared to uneducated counterpart which is consistent with the findings of Herich LC et $\mathrm{al}^{10}$ in which higher odds of exclusive breastfeeding were noted among educated mothers compared to those of uneducated counterparts.

In our study we stratified data in accordance to monthly family income of the parents, the findings revealed no significant association of breastfeeding with income status. The gender of child was found to be significantly associated with breastfeeding $(p=0.005)$. The majority of the children $(66.0 \%)$ with no history of breastfeeding were female. The weight of the child and monthly family income has no association with breastfeeding.

The breastfeeding importance is very well recognized around the world. In majority of the developing countries, only $37 \%$ of children below 6 months of age have exclusive breastfeeding. 
Breastfeeding provides many benefits to mother including protection from breast cancer and birth spacing. By promoting breast feeding universally we can prevent 823,000 annual deaths in children younger than 5 years and 20,000 annual breast cancer related deaths. The breastfeeding is simple, easy to practice and cost-effective intervention in reducing childhood morbidity and mortality. ${ }^{11}$

\section{CONCLUSION}

The study concluded that breast feeding practice is uncommon in children admitted in intensive care unit with sepsis and breastfeeding was found to be significantly associated with maternal education and gender of the child.

Copyright $\odot 09$ Aug, 2019.

\section{REFERENCES}

1. WHO. Breastfeeding [Internet]. Switzerland: World health Organization. 2015 [cited 2018]; Available from: http://www.who.int/topics/breastfeeding/en/.

2. Black RE CS, Johnson HL, Lawn JE, Rudan I, Bassani DG, Global, regional, and national causes of child mortality in 2008: A systematic analysis. The lancet. 2010; 375(9730):1969-87.

3. Bahl R, Martines J, Ali N, Bhan MK, Carlo W, Chan KY, et al. Research priorities to reduce global mortality from newborn infections by 2015 . The Pediatric infectious disease journal. 2009; 28(1):S43-S8.

4. Ladomenou F, Moschandreas J, Kafatos A, Tselentis Y, Galanakis E. Protective effect of exclusive breastfeeding against infections during infancy: A prospective study. Archives of Disease in Childhood. 2010; 95(12):1004-8.
5. Duijts L, Jaddoe VW, Hofman A, Moll HA. Prolonged and exclusive breastfeeding reduces the risk of infectious diseases in infancy. Pediatrics. 2010; 126(1):e18-e25.

6. John B, David M, Mathias L, Elizabeth N. Risk factors and practices contributing to newborn sepsis in a rural district of Eastern Uganda, August 2013: A cross sectional study. BMC research notes. 2015; 8(1):339.

7. Shiva F, Ghotbi F, Padyab M. Infant feeding and hospitalization during the first six months of life. JPMA. The Journal of the Pakistan Medical Association. 2007 Dec;57(12):599.

8. UNICEF. Children malnutrition [Internet]. Switzerland: World health Organization. [http://www.unicef.org ] 2015 Jun [cited 2018 Aug 20].

9. Onyango-Makumbi C, Omer SB, Mubiru M, Moulton LH, Nakabiito C, Musoke P, Mmiro F, Zwerski S, Wigzell H, Falksveden L, Wahren B. Safety and efficacy of HIV hyperimmune globulin (HIVIGLOB) for prevention of mother-to-child HIV transmission in HIV-1 infected pregnant women and their infants in Kampala, Uganda (HIVIGLOB/NVP STUDY). Journal of acquired immune deficiency syndromes (1999). 2011 Dec $1 ; 58(4): 399$.

10. Herich LC, Cuttini M, Croci I, Franco F, Di Lallo D, Baronciani $D$, et al. Maternal education is associated with disparities in breastfeeding at time of discharge but not at initiation of enteral feeding in the neonatal intensive care unit. The Journal of pediatrics. 2017 Mar 1; 182:59-65.

11. Victora CG, Bahl R, Barros AJ, França GV, Horton S, Krasevec J, Murch S, Sankar MJ, Walker N, Rollins NC, Group TL. Breastfeeding in the 21st century: epidemiology, mechanisms, and lifelong effect. The Lancet. 2016 Jan 30; 387(10017):475-90.

\begin{tabular}{|c|c|c|c|}
\hline \multicolumn{4}{|c|}{ AUTHORSHIP AND CONTRIBUTION DECLARATION } \\
\hline Sr. \# & Author(s) Full Name & Contribution to the paper & Author(s) Signature \\
\hline 1 & $\begin{array}{l}\text { Ali Hammad } \\
\text { Hafiz Muhammad Anwar }\end{array}$ & $\begin{array}{l}\text { Concrived basicidea, Data } \\
\text { collection, Manuscript writing. } \\
\text { Data analysis. }\end{array}$ & $\begin{array}{l}\text { Jpanwood. } \\
\text { w. Phas }\end{array}$ \\
\hline 3 & Sadia Latif & References writing. & saduo taily \\
\hline 4 & Malik M. Naeem & $\begin{array}{l}\text { Proof reading, Literature } \\
\text { review. }\end{array}$ & 7 int \\
\hline
\end{tabular}

